\title{
PEDAGANG KAKI LIMA (PKL) SEBAGAI BIBIT ENTREPRENEUR DALAM MENGATASI PENGANGGURAN
}

\author{
Bagyo Handoko*
}

\begin{abstract}
Street Trader in general is consisted of one and or some labours. This thing at the same time can lessen unemployment to remember its absorbent labour. Having beginning of business that is simple in fact they are entrepreneurs seeds that is later can implement its more business kondusif. Legal capital owned is relative smallness, and divided to fixed capital, in the form of equipments, and circulating capital. Very rare fund fulfilled from opening finance companies; usually gets fund or loan from institute or individual of who without ceremony, or stems from supplier which supplayer its merchandise. The low of basic yield street trader and way of management of very simple mony; so possibility to perform very small capital investment and also business expansion. In general this street trader labour included in category which majority stays in main job activity age (prime-age). In enableness street trader, each government city has different policy one another.
\end{abstract}

Keywords: Cloister Trader, Entrepreneur, Unemployment.

\section{PENDAHULUAN}

Pedagang Kaki Lima (PKL) dalam bahasa inggris disebut street hawker atau street trader selalu dimasukkan dalam sektor informal. Dalam perkembangannya, keberadaan PKL di kawasan perkotaan Indonesia seringkali dijumpai masalah-masalah yang terkait dengan gangguan keamanan dan ketertiban masyarakat. Kesan kumuh, liar, merusak keindahan, seakan sudah menjadi label paten yang melekat pada usaha mikro ini. Mereka berjualan di trotoar jalan, di taman-taman kota, di jembatan

Bagyo Handoko. Dosen Fakultas Ekonomi Universitas Negeri Jakarta penyebrangan, bahkan di badan jalan. Pemerintah kota berulangkali menertibkan mereka yang ditengarai menjadi penyebab kemacetan lalu lintas ataupun merusak keindahan kota. PKL dipandang sebagai bagian dari masalah (part of problem) dalam ketertiban.

Padahal, sejatinya bila keberadaannya dipoles dan ditata dengan konsisten, keberadaannya ini justru akan menambah eksotik keindahan sebuah lokasi wisata di tengah-tengah kota. Hal ini bisa terjadi apabila PKL dijadikan sebagai bagian dari solusi (part of solution). Dalam konteks penumbuhan enam juta unit usaha baru sebagai wujud komitmen pemerintah dalam 
memberdayakan usaha mikro dan usaha kecil, maka sasaran utama program seyogyanya ditujukan kepada PKL; dan sudah teruji sebagai bibit entrepreneur untuk diberdayakan menjadi unit usaha baru yang tangguh serta mampu mengatasi pengangguran.

\section{Pengertian dan Mitra Kerja Pedagang Kaki Lima (PKL)}

Sebutan Pedagang Kaki Lima

(PKL) awalnya berasal dari para pedagang yang menggunakan gerobak dorong yang memiliki tiga roda. Di atas kereta dorong itulah ia meletakkan berbagai barang dagangannya, menyusuri pemukiman penduduk dan menjajakannya kepada orang-orang yang berminat. Dengan dua kaki pedagang kaki lima plus tiga roda kereta dorong itulah, mereka kemudian dikenal sebagai pedagang kaki lima. Namun, pengertian PKL dan area tempat mereka berdagang telah mengalami banyak pergeseran. Seiring peningkatan populasi penduduk, mereka bermunculan di banyak tempat, memanfaatkan tiap celah yang dinilai memberi peluang untuk menjual dagangannya; merekapun tidak lagi harus menggunakan kereta dorong.

Mereka mengajarkan falsafah keteladanan kepada keluarganya bahwa kegetiran hidup dan kehidupan yang semakin berat dapat dilalui bila mau bekerja keras, tabah dan sabar. Mereka adalah sosok yang tidak cepat menyerah, realistis dan penuh semangat. Meski beban kehidupan semakin berat, semua dilakoni tanpa banyak mengeluh. Bagi mereka, esok berpeluang memberi kehidupan lebih baik. Mereka sebenarnya orang-orang yang patuh, sehingga tidak mengeluh saat oknum-oknum tertentu mengutip iuran. Bukankah kharakterristik seperti yang melekat pada PKL ini menjadi fondasi dasar untuk tumbuh menjadi entrepreneur besar? Bila demikian halnya, kenapa mereka ini tidak dijadikan sebagai mitra kerja bagi pemerintah? Baik sebagai mitra kerja dalam menertibkan preman, kebersihan kota, keindahan lokasi, maupun dalam menertibkan penerimaan retribusi atau Pendapatan Asli Daerah (PAD). Bahkan lebih jauh dari itu, PKL dapat dijadikan sebagai mitra kerja pemerintah dalam mengurangi kemiskinan, mengurangi pengangguran, dan sekaligus sebagai mitra dalam penataan perkotaan. Masalahnya adalah bagaimana caranya mengoptimalkan kehadiran PKL tersebut menjadi eskalator dalam proses pembangunan suatu kota?

Hampir semua stakeholders mendukung perlu dilakukan penataan PKL secara sistemik. Pemerintah ingin kotanya tertata apik, bersih, rapih, tertib, dan memperoleh PAD yang tinggi. $\quad \mathrm{PKL}$ mendambakan kenyamanan berusaha tanpa digusurgusur. Sektor formal (swasta, usaha besar, usaha menengah, usaha kecil, BUMN, BUMD, dll) menginginkan pengelolaan usaha dan pemerintah yang baik tanpa diganggu oleh PKL. Aparat Satpol dan Trantibpun tidak pernah mengharapkan bentrokan fisik dengan PKL. Untuk itu, penulis menawarkan konsep kemitraan publik dan swasta. Kerangka berpikirnya sangat sederhana. Pemerintah 
Kabupaten/Kota/Propinsi menetapkan lokasi, meregistrasi, mengawasi, mengendalikan, dan mempromosikan lokasi PKL tersebut. Pemerintah pusat membantu akses pendanaannya baik melalui APBN maupun skim perkreditan yang didesain untuk usaha mikro atau sektor informal. Sedangkan swasta, BUMN, BUMD, Usaha Besar, dan UKM menjadikan lokasi PKL tersebut sebagai sarana promosi produknya. Konsepsi ini sebenarnya bukanlah hal yang baru. Kemitraan yang melibatkan semua stakeholders di atas sudah ada dan dapat dilihat misalnya di tepi pantai Kota Makassar yang dikenal dengan lokasi Pantai Losari. Usulnya adalah bagaimana hal ini dijadikan sebagai gerakan nasional. Payung hukum sebagai dasar berpijak dari kemitraan publik dan swasta ini dapat diturunkan dari UU No.9 tahun 1995 tentang Usaha Kecil. Program konkrit kemitraan dapat dielaborasi dari jiwa pesan UU No.9/1995 tersebut untuk penataan PKL dalam menumbuhkan 6 juta unit usaha baru yang berkualitas. Hal ini sekaligus dapat mengurangi pengangguran, mengingat tenaga kerja yang dapat diserap oleh aktivitas tersebut. Jika ada kepastian seperti itu, maka para sarjana baru akan berlomba menjadi pelaku usaha yang berawal dari PKL. Di sanalah mereka akan menimba pengalaman cara berwirausaha yang baik. Alam dan lingkungan akan menjadi dosen mereka. Dengan demikian pada suatu saat nanti kita akan menyaksikan para sarjana berlomba jadi pengusaha-pengusaha mikro bukan berarti mendapatkan formulir sebagai pegawai negeri.

Para PKL dihimpun dalam suatu lokasi tertentu, dengan demikian mereka memiliki kepastian lokasi berusaha. Mencermati fenomena PKL di perkotaan, pedagang kaki lima sebagai individu warga masyarakat seyogyanya dipahami dalam konteks transformasi perkotaan. Pada hakekatnya mereka bukanlah semata-mata kelompok masyarakat yang gagal masuk dalam sistem ekonomi perkotaan. Mereka bukanlah komponen ekonomi perkotaan yang menjadi beban bagi perkembangan perkotaan. PKL adalah salah satu pelaku dalam transformasi perkotaan yang tidak terpisahkan dari sistem ekonomi perkotaan. Bagi mereka mengembangkan kewirausahaannya adalah lebih menarik ketimbang menjadi pekerja di sektor formal kelas bawah. Masalah yang muncul berkenaan dengan PKL ini lebih banyak disebabkan oleh kurangnya ruang untuk mewadahi kegiatannya di perkotaan. Konsep perencanaan tata ruang perkotaan yang tidak didasari oleh pemahaman informalitas perkotaan sebagai bagian yang menyatu dengan sistem perkotaan akan cenderung mengabaikan tuntutan ruang untuk sektor informal termasuk PKL. Kegiatan-kegiatan perkotaan didominasi oleh sektorsektor formal yang memiliki nilai ekonomis yang tinggi. Alokasi ruang untuk sektor-sektor informal termasuk PKL adalah ruang marjinal. Sektor informal terpinggirkan dalam rencana tata ruang kota yang tidak 
didasari pemahaman informalitas perkotaan. Apabila kita dapat menerima alur pikir dan fakta yang disajikan di atas bahwa PKL merupakan bagian yang tidak terpisahkan dari sistem perekonomian nasional khususnya dalam penyerapan tenaga kerja dan sebagai bibit entrepreneur maka PKL sangat berhak memperoleh kenyamanan berusaha berupa penciptaan iklim berusaha yang kondusif dari pemerintah. Dalam konteks ini, Kementerian Koperasi dan UKM menawarkan kerjasama dengan pemerintah kota/kabupaten/propinsi program penataan \& pemberdayaan PKL yang dilakukan melalui pendekatan kelembagaan Koperasi. Jadi kelompok PKL yang tadinya berhimpun dalam bentuk paguyupan, kelompok, atau sentra diarahkan menjadi lembaga yang berorientasi peningkatan kesejahteraan ekonomi.

\section{Ekonomi Rakyat Sebagai Penyelamat Ekonomi Nasional}

Dalam perspektif ekonomi diartikan bahwa krisis ekonomi dewasa ini sudah amat parah; jika dibiarkan mengakibatkan kebangkrutan perekonomian nasional. Meskipun tidak pernah menyebutkan bahwa krisis yang melanda bangsa Indonesia dewasa ini sudah berciri multidimensi, namun yang paling sering disebutkan di media masa adalah krisis ekonomi bukan krisis politik atau krisis hukum, bahkan krisis moral. Hal ini dapat disebabkan karena tiga dekade orde baru pembangunan ekonomi memiliki peranan yang sangat dominan dari perusahaan-perusahaan konglomerat. Kini ketika konglomerat sudah rontok, sulit dibayangkan untuk bangkit kembali karena utang-utangnya sangat besar; ekonomi Indonesia secara keseluruhan dikatakan dalam keadaan krisis parah.

Di sisi lain, diagnosis para ekonom bersifat pesimistik masih jauh lebih kuat dibanding diagnostik karena pada umumnya pakar-pakar ekonomi kita lebih banyak menggunakan data makro sekunder dan tersier di bidang keuangan. Sebaliknya data mikro ekonomi rakyat memang tidak tercatat dalam statistik secara baik, tidak masuk dalam perhitungan; inilah para ekonom makro yang disebut dengan illegal atau hidden economy. Ekonomi rakyat dimanapun di daerah-daerah telah bangkit yang disebut sebagai Usaha Kecil Menengah (UKM) yang berkembang di mana-mana dengan pendanaan mandiri atau melalui dana-dana keuangan mikro seperti pegadaian, koperasi atau lembagalembaga keuangan mikro informal di pedesaan.

Berkembangnya UKM di satu sisi dapat sebagai penyalamat ekonomi nasional mengingat kontribusinya dalam Pendapatan Domestik Bruto (PDB) sangat signigfikan; hal ini dikatakan oleh Menteri Negara Koperasi dan UKM (Menegkop \& UKM) bahwa UKM menyumbang 53,3 persen atau sebesar Rp1.778,7 triliun dari total Produk Domestik Bruto (PDB) tahun 2006 yang mencapai Rp3.338,2 triliun. Sedangkan dari sisi tenaga 
kerja UKM mampu menyerap jumlah tenaga kerjanya mencapai 85,4 juta orang atau 96,18 persen terhadap seluruh tenaga kerja Indonesia dengan jumlah populasi UKM pada 2006 mencapai 48,9 juta unit usaha atau 99,98 persen terhadap total unit usaha di Indonesia.

Pedagang Kaki Lima (PKL) yang dikelompokkan dalam sektor informal sering dijadikan sebagai 'kambing hitam' dari penyebab kesemrawutan lalu lintas maupun tidak bersihnya lingkungan. Meskipun demikian $\mathrm{PKL}$ ini sangat membantu kepentingan masyarakat dalam menyediakan lapangan pekerjaan dengan penyerapan tenaga kerja secara mandiri atau menjadi safety belt bagi tenaga kerja yang memasuki pasar kerja, selain untuk menyediakan kebutuhan masyarakat golongan menengah ke bawah.

Pada umumnya sektor informal sering dianggap lebih mampu bertahan hidup survive dibandingkan sektor usaha yang lain. Hal tersebut dapat terjadi karena sektor informal relatif lebih independent atau tidak tergantung pada pihak lain, khususnya menyangkut permodalan dan lebih mampu beradaptasi dengan lingkungan usahanya. Bukti-bukti tersebut menggambarkan bahwa pekerjaan sebagai PKL merupakan salah satu pekerjaan yang relatif tidak terpengaruh krisis ekonomi karena dampak krisis ekonomi tidak secara nyata dirasakan oleh pedagang kaki lima. Dalam hal ini PKL mampu bertahan hidup dalam berbagai kondisi, sekalipun kondisi krisis ekonomi. Eksistensi sektor informal seperti PKL memiliki peran penting sebagai penyangga distorsi sistem ekonomi. Namun di saat yang sama, ekonomi informal juga merupakan masalah, sehingga perlu direspon dengan politik ekonomi dan kebijakan yang tepat. Salah satu pendekatan yang dilakukan oleh Kementerian Koperasi dan UKM adalah melalui Program Penataan dan Pemberdayaan Pedagang Kaki Lima dengan fasilitasi Bantuan Perkuatan Sarana Usaha sebagai stimulator dan katalisator bagi Pemerintah Kabupaten/Kota. Program ini sudah berjalan dua tahun anggaran. Dalam program tersebut, Kementerian Negara Koperasi dan UKM bersinergi dengan Pemerintah Propinsi atau Kabupaten/Kota untuk memberdayakan PKL melalui Koperasi. Melalui pola ini diharapkan PKL dapat menjadi suatu solusi dalam memecahkan penumbuhan usaha baru sekaligus akan berdampak terhadap penyerapan tenaga kerja.

\section{Upaya Mengatasi Kesemerautan dan Pengangguran}

Problema penting yang dihadapi negara-negara dunia ketiga adalah merebaknya kontradiksi ekonomi politik evolusi pertumbuhan perkotaan di negara-negara tersebut. Pertumbuhan konsentrasi penduduk di kota-kota besar negara-negara dunia ketiga terjadi dengan kecepatan yang sangat tinggi. Tetapi, pertumbuhan kota-kota tersebut ternyata tidak diikuti dengan kecepatan yang sebanding oleh pertumbuhan industrialisasi. 
Fenomena ini oleh para ahli disebut sebagai "urbanisasi berlebih (over urbanization)". Istilah ini menggambarkan bahwa tingkat urbanisasi yang terjadi terlalu tinggi melebihi tingkat industrialisasi yang dicapai oleh evolusi suatu masyarakat. Arus migrasi desa-kota yang cukup besar tidak semuanya terserap di sektor industri modern di kota, karena keterbatasan sektor industri modern dan tidak semua migran memiliki skill atau kemampuan untuk masuk ke sektor industri modern tersebut. Hal ini mengakibatkan para migran yang tidak dapat masuk ke sektor industri modern lebih memilih sektor informal yang relatif mudah untuk dimasuki. Agar tetap dapat bertahan hidup (survive), para migran yang tinggal di kota melakukan aktivitas-aktivitas informal (baik yang sah dan tidak sah) sebagai sumber mata pencaharian mereka. Hal tersebut dilakukan dengan pertimbangan daripada menjadi pengangguran yang tidak memiliki penghasilan atau memiliki penghasilan tetapi rendah dan tidak tetap.

Beberapa jenis "pekerjaan" yang termasuk di dalam sektor informal; salah satunya adalah pedagang kaki lima, seperti warung nasi, penjual rokok, penjual koran dan majalah, penjual makanan kecil dan minuman, dan lain-lainnya. Mereka dapat dijumpai di pinggirpinggir jalan di pusat-pusat kota yang ramai akan pengunjung. Mereka menyediakan barang-barang kebutuhan bagi golongan ekonomi menengah ke bawah dengan harga yang dapat dijangkau oleh golongan tersebut. Tetapi, tidak jarang mereka yang berasal dari golongan ekonomi atas juga ikut menyerbu sektor informal. Sektor informal memiliki peranan penting dalam memberikan sumbangan bagi pembangunan perkotaan, karena sektor informal mampu menyerap tenaga kerja (terutama masyarakat kelas bawah) yang cukup signifikan sehingga mengurangi problem pengangguran di perkotaan dan meningkatkan penghasilan kaum miskin di perkotaan. Selain itu, sektor informal memberikan kontribusi bagi pendapatan pemerintahan kota. Namun, pertumbuhan sektor informal yang cukup pesat tanpa ada penanganan yang baik dapat mengakibatkan ketidakteraturan tata kota.

Sebagaimana kita ketahui, banyak pedagang kaki lima yang menjalankan aktivitasnya di tempattempat yang seharusnya menjadi Public Space; yang merupakan tempat umum di mana masyarakat bisa bersantai, berkomunikasi, dan menikmati pemandangan kota. Tempat umum tersebut bisa berupa taman, trotoar, halte bus, dan lainlain. Trotoar yang digunakan untuk berjualan dapat mengganggu para pejalan kaki, seringkali kehadiran pedagang kaki lima tersebut mengganggu arus lalu lintas karena para konsumen pengguna jasa memarkirkan kendaraannya di pinggir jalan. Ketidakteraturan tersebut mengakibatkan Public Space kelihatan kumuh sehingga tidak nyaman lagi untuk bersantai ataupun 
berkomunikasi. Untuk mengatasi masalah sektor informal, diperlukan ketegasan dari pemerintah kota. Selama ini, pemerintah hanya melakukan "penertiban" dalam mengatasi masalah sektor informal. Namun hal tersebut terbukti tidak efektif, karena setelah para pedagang kaki lima tersebut ditertibkan maka beberapa hari kemudian mereka akan kembali ke tempat semula untuk berjualan. Selain itu, ada kecenderungan tempat yang digunakan untuk berjualan tersebut diperjualbelikan, padahal mereka berjualan di lokasi Public Space yang merupakan milik pemerintah. Hal tersebut dapat dikatakan sebagai tindakan melanggar hukum. Hal pertama yang harus dilakukan oleh pemerintah kota adalah relokasi bagi para pedagang kaki lima. Pemerintah harus menyedikan tempat yang dapat digunakan mereka untuk berjualan. Hal tersebut ditujukan agar pedagang kaki lima tidak mengganggu kepentingan umum karena berjualan di lokasi Public Space. Selain itu, relokalisasi dapat menumbuhkan perasaan aman bagi pedagang karena mereka tidak perlu khawatir ditertibkan oleh aparat pemerintah.

Selain itu, pemerintah harus melakukan proteksi bagi pedagang kaki lima sebagai imbalan atas kontribusi yang telah diberikan oleh sektor informal. Proteksi tersebut ditujukan agar pedagang kaki lima tersebut tidak kalah bersaing dengan pedagang besar yang telah memiliki nama. Karena apabila mereka sampai kalah bersaing dan harus gulung tikar, itu berarti akan terjadi pengurangan kesempatan kerja dengan kata lain menambah pengangguran. Sektor informal sebagai sektor alternatif bagi para migran cukup memberikan sumbangan bagi pembangunan perkotaan. Selain membuka kesempatan kerja, sektor informal juga dapat meningkatkan pendapatan bagi masyarakat kota. Namun, pertumbuhan sektor informal yang pesat tanpa mendapat penanganan yang baik dan terencana akan menimbulkan persoalan bagi kota. Untuk itu, pemerintah kota harus jeli dalam menangani masalah sektor informal itu; sehingga sektor informal dapat tumbuh dengan subur tanpa mengganggu kepentingan dan sekaligus mengurangi pengangguran.

\section{PENUTUP}

Sektor ekonomi yang umumnya berkembang secara cepat adalah sektor perdagangan kecil dan jasa; sektor ini sangat tergantung pada jarak dan tingkat kepadatan penduduk. Persebaran penduduk yang berjauhan dan tingkat kepadatan penduduk yang rendah akan memperlemah sektor perdagangan eceran dan jasa yang berakibat peluang kerja berkurang. Sebaliknya, semakin dekat penduduk maka interaksi antar mereka mendorong kegiatan sektor perdagangan dan jasa. Seharusnya pedagang kecil mendapat tempat yang mudah untuk berusaha karena telah membantu pemerintah daerah mengurangi pengangguran. Pada waktunya, pengusaha kecil membayar pajak kepada pemerintah. Dengan 
menstimulir usaha pedagangan eceran dan jasa, pertukaran ekonomi yang lebih cepat dapat terjadi sehingga menghasilkan investasi yang lebih besar. Adanya pusat-pusat pedagang kaki lima yang efisien dan teratur dapat menarik lebih banyak investasi bagi ekonomi daerah jangka panjang.

\section{DAFTAR PUSTAKA}

Bapenas. 2003. Perekonomian Indonesia Tahun 2003: Prospek dan Kebijakan.

Ibnu Widiyanto. 1998. "Koperasi sebagai Pelaksana Distribusi Barang: Realita dan Tantangan: Sebuah Pendekatan Pragmatis". NET Seminar: Merancang dan Memelihara Jaringan Distribusi Barang Yang Tangguh dan Efisien di Indonesia. 1-5 September 1998 FORUM TI-ITS.

MiIler, Roger L. 1995. Intermediate Microeconomics. 2nd Edition. Singapore: Mc Graw Hill.

Mubyarto. 2003. "Dari Ilmu Berkompetisi ke Ilmu Berkoperasi", Jurnal Ekonomi Rakyat. Artikel Tahun II - No. 4 - Juli 2003.

Nurul Indarti. 2007. "Rendah, Adopsi Teknologi Informasi oleh UKM di Indonesia". Pusat Informasi Perkoperasian. Dewan Koperasi
Indonesia.

Edisi 281/Januari/Th.XXIV/2007.

UU No. 25 Tahun 1992 tentang Perkoperasian.

Sri-Edi Swasono. 2002. "Sistem Ekonomi Indonesia". Jurnal Ekonomi Rakyat. Artikel Tahun I No- 2 - April 2002.

Siebert Horst. 2006. "Locational Competition: A Neglected Paradigm in the International Division of Labour". Journal Compilation. Blackwell Publishing, Ltd.

Surico, Paolo. 2003. "Geographical Concentration and Increasing Returns". Journal of Economics Survey. Vol.17:5.

Yulyani, 2008. "PKL Dibina Atau Dibinasakan". Kompas: 21 Agustus 2008.

Van Oort, Franciscus Gustaaf. 2002. Agglomeration, Economic Growth and Innovation: Spatial Analysis of Growth-and R\&D Externalities in The Netherlands. Netherland: Timbergen Institute Research Series.

www.depkop.go.id. "Dana Bergulir Difokuskan ke Sektor Usaha Produktif"Monday, 09 July 2007. www.menkokesra.go.id/content/view/ 3391/1/. "UKM Sumbang 53,3 Persen Total PDB Indonesia 2006", 20-03-2007.

www.menlh.go.id. "Kriteria Usaha Kecil". 28 Agustus 2007. 